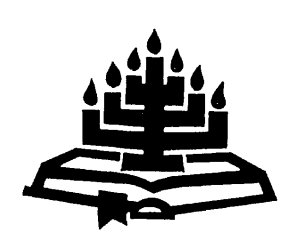

\title{
Prediking en die gesindheid van hoorders. Basisteoretiese perspektiewe va nuit Hebreërs
}

\author{
F.P. Kruger \& C.J.H. Venter \\ Vakgroep Praktiese Teologie \\ Skool vir Kerkwetenskappe \\ Potchefstroomse Universiteit vir $\mathrm{CHO}$ \\ POTCHEFSTROOM \\ E-pos: fercel@lantic.net \\ kwscjhv@puknet.puk.ac.za
}

\begin{abstract}
Preaching and the attitude of hearers. Basis-theoretical perspectives from the Hebrews sermon
\end{abstract}

The issue dealt with in this article is the extracting of certain basistheoretical perspectives from Hebrews, reminding preachers and hearers that preaching and attitude are interrelated concepts. Expressions in which preaching and attitude are stated explicitly are investigated, and concepts indicating certain dimensions of attitude as reflected in the Hebrews sermon are discussed. This exposition is followed by selected perspectives for the praxis of equipment in ministering the Word to the congregation.

\section{Opsomming}

Prediking en die gesindheid van hoorders. Basisteoretiese perspektiewe va nuit Hebreërs

In dié artikel word basisteoretiese perspektiewe vanuit Hebreërs gebied. Die doel hiermee is om predikers en hoorders se aandag opnuut weer daarop te vestig dat prediking en die gesindheid teenoor prediking verbandhoudende begrippe is. In die artikel word uitdrukkings wat direk te make het met prediking en gesindheid ondersoek en aandag word ook gegee aan sekere uitdrukkings wat betrekking het op hoorders se gesindheid teenoor prediking. Ten slotte word enkele perspektiewe gebied met die oog op die praktyk van die toerusting van die gemeente deur die prediking. 


\section{Inleiding}

Gedurende die afgelope aantal jare is verskillende dimensies van die prediking betrek in wetenskaplike ondersoeke. Enkele voorbeelde kan hierdie stelling nader toelig. Die preekgebeure is in homiletiese ondersoek betrek deur oder andere Long (1989:57) en Cradock (1991: 23). Vroeër het Zerfass (1982:30) oor die prediking as prosesgebeure in ekklesiale konteks gehandel. Binne hierdie besinning val sekere fokuspunte op, byvoorbeeld die preekgebeure in verbondenheid met die bediening in sy geheel (Smit, 1995:7) en gemeente en prediking (Pieterse, 1991:3). Kommunikasie-aspekte van die verkondiging word ook nader ondersoek (Vos, 1994:10). Wat opvallend is, is dat homiletiese ondersoek ook sterk gerig word op die hoorder van die prediking. Dit is veral Dingemans (1991:15) wat pleit vir 'n hermeneutiek van die hoorder. Hierin word hy in Suid-Afrika nagevolg deur Vos (1994:10). Die hoorder en die prediking ontvang ook aandag in die navorsing deur De Wet (1995:23) en Van der Vyver (1990:4).

Uit bogenoemde uiteensetting is dit duidelik dat vanuit die navorsing oor die plek van die hoorder in die prediking en ook vanuit die navorsing oor die gesindheid van die hoorder, die klem in navorsing ook fokus op die verandering van die gesindheid van hoorders langs die weg van die prediking. Op grond van bogenoemde navorsing blyk die aktualiteit van die onderwerp wat handel oor die prediking aan hoorders ten opsigte van hulle gesindhede.

Die uitgangspunt van die artikel is dat prediking in die gemeentelike bediening as een van die belangrikste wyses van toerusting beskou moet word (Spring, 1986:6; Long, 1989:20; Burger, 1995:126; Vorster, 1998:22). In hierdie artikel sal primêr gefokus word op die ontginning van relevante gegewens uit die Hebreërspreek ten opsigte van prediking en die gesindheid van hoorders. Onder Nuwe-Testamentici bestaan daar redelike konsensus dat Hebreërs 'n preek met 'n briefslot is (Venter, 2001:1-2; Opperman, 1995:26; Ellingworth, 1993:61; Pfitzner, 1993:3; Coetzee, 1986:1-9). Aangesien Hebreërs ook as 'n preek beskou kan word, is dit noodsaaklik om toepaslike gegewens aangaande die prediking as toerusting op 'n basisteoretiese wyse vanuit Hebreërs te ondersoek. Die noodsaak van navorsing oor prediking as toerusting van hoorders ten opsigte van hulle gesindheid blyk verder uit die feit dat prediking en gesindheid in die Hebreërspreek interafhanklike begrippe is (Conn, 1984:230). Die aspek van gesindheid teenoor die prediking is Skriftuurlik nog nie genoegsaam gefundeer nie en laat so ruimte vir navorsing in besonder uit die brief aan die Hebreërs (Mack \& Swavely, 1996:59). 


\section{Omskrywing van terminologie}

Binne die raamwerk van die onderwerp moet die begrippe prediking en gesindheid kortliks omskryf word.

\section{- Werksdefinisie van prediking}

Prediking is die brugbou tussen die Bybel en die moderne wêreld waardeur God Drie-enig deur sy geroepe dienskneg tot die gemeente spreek.

\section{- Werksdefinisie van gesindheid}

Vir die doel van hierdie artikel word aangesluit by die WAT se definisie wat gesindheid onder andere omskryf as "'n innerlike gevoel of houding" en "'n innerlike ingesteldheid" (WAT, 1972:180).

\section{Ba sisteoretiese verkenning van prediking va nuit die Hebreërspreek}

Die verskillende Woordbedieningsbegrippe wat in die Hebreërspreek gebruik word, dui op die veelkantigheid van 'n preek (Venter, 1993:252). Die begrippe staan in 'n noue band met die verskillende gestaltes van preekkommunikasie. Elke preek bevat dus elemente van elkeen van hierdie Woordbedieningsbegrippe en vat die kern van die aard van prediking saam. Die volgende Woordbedieningsbegrippe kom na vore in die Hebreërspreek en word in die volgende paragraaf basisteoreties verken.

\subsection{Ontleding van die Woordbedieningsbegrippe uit Hebreërs}

\subsubsection{P a r a kal $\varepsilon \omega-P$ a r áklhsi"}

(Heb. 3:13; Heb. 6:18; Heb. 12:5; Heb. 13:19; Heb. 13:22).

Louw en Nida (1989b:407) plaas dié begrip binne die subdomein van vra of versoek. Dié Woordbedieningsbegrip beklemtoon die gedagte van diepe erns of die gedagte van pleit (Louw \& Nida, 1989b:185). Pieterse $(1985: 9)$ dui die tweekantige betekenis van die Woordbedieningsbegrip aan, naamlik vermaning en vertroosting. Venter (1988:145) en Vorster (1995:460) dui aan dat die begrip kan beteken om iemand vertroostend by te staan of om iemand te vertroos as daad van God. Die begrip gee uitdrukking aan sowel die indikatiewe komponent van troos in Christus as die imperatiewe komponent van sorg langs die weg van vermaning en vertroosting met die oog op die verandering van lewensrigting (Williams, 1996:4 \& Louw, 1993:30). 
In die Hebreërspreek word die begrip soos volg gebruik:

- In Hebreërs 3:13 word die gelowiges opgeroep om mekaar daagliks te bemoedig (Kistemaker, 1984:94; Ellingworth, 1993:223). Attridge (1989:33) verklaar die begrip in sy uiteensetting as aanspoor, terwyl Ellingworth (1993:224) die begrip verklaar as vertroosting en bemoediging. Die bemoediging van die gemeente word in dié gedeelte verbind aan God se roepstem wat tot die gelowiges kom (Murray, 1996:133).

- In Hebreërs 13:19 en 22 dui die begrip pa r a ka l Éw op vermaning. Die gelowiges word vermaan om voorbidding te doen vir die belangrike werk van die voorgangers (Barton et al., 1997:245).

- In Hebreërs 6:18 word die begrip pa r a kl h s in gebruik. In die konteks van dié gedeelte hou die Hebreërsskrywer God se bemoediging aan hulle voor. Hy spoor die gelowiges aan om vas te hou aan die hoop wat hulle het (Ellingworth, 1993:223).

- In Hebreërs 12:5 word die begrip th" paraklhsew" gebruik as aanduiding van die vermaning van die Skrif. Die lesers word opgeroep om altyd te let op dit wat die Woord aan hulle voorhou.

- In Hebreërs 13:22 word die begrip tou' logou th" parakl hsew" gebruik as aanduiding van die vermanende aspek van die prediking wat deur die preek tot die gemeente kom (Ellingworth, 1993:223).

\subsubsection{L a | $\dot{\varepsilon} \omega$}

(Heb. 2:2; Heb. 2:3; Heb. 2:5; Heb. 6:9; Heb. 12:25; Heb. 13:7)

Dié woord is die mees alledaagse woord vir praat (Wilson, 1987:7) en dié begrip word ses maal in die Hebreërspreek gebruik: Hebreërs 2:2, $2: 3,2: 5,6: 9,12: 25,13: 7$. Hierdie woord, hou selfs die moontlikheid in van meer informele gesels (Louw \& Nida, 1989:397). In die Hebreërspreek word die woord soos volg gebruik:

- In Hebreërs 2:2 en 2:3 word die betekenisnuanse van dié woord, naamlik praat, gebruik as kontras tussen die woord wat, enersyds deur engele gespreek is en andersyds die woord wat deur God gespreek is (Guthrie, 1996:80). Die gebruik van die passief I a I h q el " bevestig die feit dat die praat God se daad is (Ellingworth, 1993:141). Die oortreding waarvan in dié verse sprake is, dui elke keer op 'n innerlike gesindheid van opstand teen die Woord (Mahan, 1989:8). Die hoorders word in dié verse vermaan om die Woord van redding nie te minag nie, want dit is 'n Woord wat van God in en deur Jesus Christus kom. 
- In Hebreërs 2:5 word aangesluit by Hebreërs 2:1-4 waar gehandel is oor die verkondiging van Jesus Christus. Die Hebreërsskrywer werk die implikasie wat die prediking van Christus vir gelowiges inhou verder uit (Bruce, 1990:71). Hiervoor word die woord I a l o umen gebruik. Die praesens wat gebruik word, kan verstaan word as "dit waarvan ons praat " (Ellingworth, 1993:147). God se Woord vorm dus die inhoud van die prediking.

- In Hebreërs 13:7 word die begrip praat weereens gebruik. Ellingworth (1993:703) toon aan dat die Woordbedieningsbegrip | a | $\varepsilon \omega$ 'n onderliggende begrip is wat telkemale in die Hebreërspreek aan die orde gestel word. In vers 7 het die begrip God se Woord as objek. Daarom skerp die Hebreërsskrywer die lesers in die preek op om aan hulle voorgangers wat die Woord verkondig te dink (Vines, 1993:239240).

\subsubsection{E ủag gel ízo ma i}

(Heb. 4:2; Heb. 4:6)

Dié Woordbedieningsbegrip word op twee plekke in die Hebreërspreek gebruik, naamlik Hebreërs 4:2 en Hebreërs 4:6. Louw en Nida (1989a:107) toon aan dat die begrip dui op die vertel of oordra van goeie nuus. Louw en Nida (1989b:410) plaas die begrip binne die subdomein van inlig, informasie of aankondig. Die begrip kan volgens Louw en Nida (1989b:412) ook dui op die aankondiging van die evangelie. In Hebreërs word die begrip soos volg gebruik:

- In Hebreërs 4:2 word die uitdrukking ej́men euhggelismenoi aangetref. Die perfektumpassief wat gebruik word, dui op die feit dat die evangelie (die blye boodskap) alreeds vir 'n lang tyd aan die gelowiges verkondig is sodat 'n mens kan sê dat hulle geëvangeliseer is (Hurst, 1990:106; Ellingworth, 1993:241). Saam met die werkwoord e's men word 'n perifrastiese konstruksie gevorm wat die gedagte van voortdurende aktiwiteit uitdruk - 'n aktiwiteit wat in die verlede begin het en tot in die hede voortduur. Die voornaamwoord jime $\hat{\imath}^{\prime \prime}$ word nie gebruik nie, juis om klem te plaas op die woordbedieningsbegrip (Kistemaker, 1984:109). Tot die blye boodskap wat die gelowiges ontvang het, behoort ook die belofte (epaggel i " ") van Hebreërs 4:1. Dié begrip word veertien maal in Hebreërs aangetref en die werkwoord vier maal. Die uitdrukking ol logo" th" akoh" dui op die Woord wat gehoor is (Barton et al., 1997:48). Die gedagte is dat die Woord wat so duidelik en hoorbaar verkondig is, nie versmaai moet word nie. 
- In Hebreërs 4:6 word die aoristusvorm eujag gel i s q ent e" gebruik. Hier dui die vorm van die werkwoord op dit wat met Israel in die woestyn gebeur het (Guthrie, 1996:114 \& Ellingworth, 1993:241). Die Israeliete het die Woord wel gehoor, maar nie daarop ag geslaan nie.

\section{$3.1 .40 J \log 0 "$}

(Heb. 4:2)

Dié Woordbedieningsbegrip word een maal in Hebreërs gebruik, naamlik in Hebreërs 4:2. Dié Woordbedieningsbegrip word gebruik binne die konteks van die gesindheid van onwilligheid om die boodskap wat verkondig is te gehoorsaam (Lane, 1991:40).

Louw en Nida (1989:417) plaas die begrip I óg o s binne die subdomein van prediking oftewel verkondiging. Die Woordbedieningsbegrip dui volgens Louw en Nida op die inhoud van dit wat oor Christus verkondig word, met ander woorde die begrip dui op dit wat verkondig word. Volgens Guthrie (1996:111) dui die begrip op die Woord wat duidelik en hoorbaar verkondig word, met ander woorde die boodskap. Die geloofsaanvaarding van die Woord wat gehoor word, word in die vers benadruk. Die kwalitatiewe genitief $t \hat{\eta}^{\prime \prime}$ a ko $\hat{\eta}^{\prime \prime}$ benadruk die feit dat die Woord gehoor moet word. Volgens Barton et al. (1997:49) word die hoorder met die Woordbedieningsbegrip voor die Christusgebeure geplaas en sodoende tot 'n beslissing opgeroep. Die hoor van die Woord moet lei tot geloof daarin. Die Woord van God het tot inhoud alles wat God gedoen en gesê het.

\subsubsection{M artur $\varepsilon \omega$}

(Heb. 10:15)

Dié Woordbedieningsbegrip word een maal in Hebreërs gebruik, naamlik in Hebreërs 10:15. M a r tur $\varepsilon \omega$ is afgelei van die woord már t u" wat 'n getuie in 'n regsaak beteken. ' $n$ Getuie is 'n persoon wat vertel wat hy persoonlik gesien en gehoor het van die saak wat aan die orde is (Barton et al., 1997:156). Die voorwaarde wat aan 'n getuie gestel word, is dat hy die waarheid moet praat. Die skrywer van Hebreërs beklemtoon die feit dat dit wat hy aan hulle verkondig, deur die Heilige Gees aan hulle betuig word (Flanigan, 1997:207). Die Heilige Gees getuig oor dit wat die Woord sê en sê eenvoudig dit wat God openbaar (Vorster, 1995:457).

Toegepas op prediking beteken hierdie aksent dat prediking moet getuig van dit wat die Woord sê. Die vrymoedigheid van die prediker om die Woord te bring, lê nie in homself of in oratoriese vermoëns opgesluit nie, 
maar in die vaste wete dat die Heilige Gees getuig dat die Woord waar is. Louw en Nida (1989a:418) plaas ma r t u r $\varepsilon ́ \omega$ binne die subdomein van om getuie te wees of om te getuig. Die gedagte wat met dié begrip beklemtoon word, is die feit dat omdat die Heilige Gees God se Woord ken, kan Hy ook hiervan getuig. Hy is immers die Spreker (Prediker) van die Woord asook die Openbaarder. Prediking as ma r t u r e în kan daarom net geskied indien die prediker en hoorders erns maak met die feit dat prediking die getuienis is van dit wat die Skrif sê.

\subsection{Samevattende basisteoretiese perspektiewe}

Bogenoemde Woordbedieningsbegrippe wat in Hebreërs gebruik word om prediking mee te beskryf, staan nie los van mekaar of teenoor mekaar nie. Elke preek bevat elemente van elkeen van hierdie Woordbedieningsbegrippe. Die volgende aspekte van prediking word deur hierdie begrippe belig, naamlik:

- Prediking as paraklese. Die tweekantigheid van prediking as vermaning en vertroosting word deur die begrip aangeraak. Prediking mag nooit ontaard as 'n gesprek uit die hoogte wat met allerlei moets en moenies gepaard gaan nie. Die balans tussen vermaning en vertroosting moet in berekening gebring word.

- Prediking as 'n gesprek. Prediking moet as kommunikasie eg en eenvoudig wees en moet God se Woord as inhoud hê.

- Prediking as evangelieverkondiging. Prediking moet aan hoorders die blye boodskap bring met die appèl om die toesegging daarvan deur die geloof toe te eien.

- Prediking as getuienis. Prediking moet aan hoorders 'n getuienis van die waarheid van die Woord bied.

Die verskillende Woordbedieningsbegrippe in die Hebreërspreek word in 'n noue verband gebruik met sekere leemtes in die gesindheid van die hoorders wat opgemerk word. Die volgende gesindhede word deur die Woordbedieningsbegrippe betrek:

- Die gesindheid van getrouheid in die vashou aan die hoop wat daar in Jesus Christus is. Gelowiges moet as uitvloeisel van die "aan Christus vashou", mekaar ook vashou en met mekaar bemoeienis maak.

- Die negatiewe gesindheid van minagting van God se Woord word deur dié Woordbedieningsbegrippe uitgewys.

- Prediking moet as 'n saak van erns deur die prediker en hoorder beskou word. Die hoorder moet dit wat verkondig word, deur die geloof vir himself toeëien. 


\section{Basisteoretiese verkenning van begrippe uit Hebreërs wat direk met gesindheid te make het}

Die Hebreërsprediker vermaan die hoorders tot sewe maal toe oor hulle gesindheid, omdat hy sekere leemtes in hulle gesindheid bemerk het en hy wil hê dat hulle insig in dié situasie moet kry. In die Hebreërspreek word drie begrippe gebruik wat direk verband hou met die gesindheid van die hoorders, naamlik:

- parrhsía - vrymoedigheid

- spoudázw - beywer

- qarrounta" - vrymoedigheid

Dié begrippe word gesamentlik sewe maal in die Hebreërspreek gebruik, naamlik in Hebreërs 3:6, 4:11, 4:16, 6:11, 10:19, 10:35 en 13:6.

\subsection{P ar rhs ía}

(Heb. 3:6, 4:16, 10:19 en 10:35)

Louw en Nida (1989a:306) plaas dié begrip onder die subdomein van moed oftewel vrymoedigheid. Volgens Louw en Nida (1989a:307) dui die begrip op die vrymoedigheid wat ook onder moeilike omstandighede geopenbaar moet word. Herholdt (1995:128) sluit by die gedagte aan en toon aan dat die begrip op die morele moed of karakter van 'n persoon kan dui. Dit word as 'n tegniese term gebruik om 'n Griekse burger se demokratiese reg van vryheid van spraak mee aan te dui. So 'n burger kon in teenstelling met die slawe sy opinie vryelik in die publiek lug. Die opinie wat gelug word, het egter dikwels aanleiding gegee tot weerstand.

Dié begrip word soos volg in die Hebreërspreek gebruik:

- In Hebreërs 3:6 word die gelowiges opgeroep om die vrymoedigheid tot die einde onwrikbaar vas te hou. Volgens Bruce (1990:94) dui die opdrag rondom vrymoedigheid hier daarop om vas te hou aan dit wat reeds gegee is. Die gesindheid van die gelowige word verbind aan hoop (Mahan, 1989:14; Bromiley, 1985b:795). In Hebreërs 3:1-6 het die prediker die hoorders daarop gewys dat Jesus groter is as Moses. Moses was maar deel van die huis wat God self gebou het. In Hebreërs 3:6b begin die prediker reeds handel oor die saak waaroor hy in Hebreërs 3:7-4:11 gaan preek, naamlik dat niemand die rus van God kan ingaan as hy nie aan sy Woord gehoorsaam is en met moed en oortuiging aan die hoop vashou nie (Evans, 1984:91). In Hebreërs 3:12 noem die prediker die gevaar wat die hoorders bedreig, naamlik afvalligheid. Teenoor die gevaar van afvalligheid staan die gesindheid 
van vrymoedigheid of openhartigheid ten opsigte van die verkondiging van die Woord (Mack \& Swavely, 1996:10).

- In Hebreërs 4:14-16 word 'n nuwe afdeling begin. Die argument wat reeds in Hebreërs 3 aangevoor is, word nou verder in diepte bespreek (Brown, 1994:229). In hoofstuk 3 is veral gehandel oor die vashou aan Jesus Christus. In Hebreërs 4:16 gee die prediker sy konklusie op grond van vers 14 en 15. Op grond van dit wat Jesus bewerk het, kan die gelowige openlik, sonder dat iets hom verhinder, met ander woorde met vrymoedigheid, na die genadetroon gaan. In die uitdrukking prosercwmeqa ouh meta Vparrhsia" word dit wat die gelowige kan en mag doen, saamgevat (Brown, 1994:227). Die vaste grond van die gaan tot God se troon word gevind in die hoëpriesterlike werk van Jesus Christus (Heb. 7:25, 10:22, 11:6, 12:18 en 22). Die begrip parrhsia dui die hoe van die nader tot God aan; naamlik met vrymoedigheid.

- In Hebreërs 10:19 vestig die prediker opnuut weer die hoorders se aandag op die vrye toegang wat hulle tot God het, omdat Christus die weg hiertoe gebaan het. In Hebreërs 10:19 word die tweede gedeelte, naamlik die praktiese en vermanende gedeelte van die preek ingelei deur die opdrag tot vrymoedigheid (Peters, 1999:62; Vines, 1993: 137). Die voorreg om tot die hemelse heiligdom te nader, lê opgesluit in die wete dat Christus die weg gebaan het.

- In Hebreërs 10:35 word die hoorders vermaan om nie hulle vrymoedigheid weg te werp nie. Die vrymoedigheid om deur Christus tot God te nader moet nie prysgegee word nie. Die vrymoedigheid (voorreg) om tot God te nader mag nie ongebruik (mh Va pobalhte) gelaat word of weggegooi word soos iets wat nie meer waarde het nie (Guthrie, 1996:223). Die aoristus imperatief benadruk die gedagte van nougesetheid (Ellingworth, 1993:551). Die motivering vir die opdrag word in die volgende gevind, naamlik $h$ Hi" elel megalhn misqa. podosian. Die woord htil benadruk 'n sekere eienskap wat die hoorders se lewe moet kenmerk. Volgens Ellingworth (1993:551) dui die gebruik van die woord ook op 'n bevestiging van dit wat genoem word, naamlik dat hulle vrymoedigheid 'n groot genadeloon inhou. Die genadeloon behels onder andere die gemeenskap met God en om deel te hê aan sy seëninge soos onder andere die swthr ía (Heb. 1:14, 2:10, 5:9) en die eleo" kaiVcavin (Heb. 4:16). Die opregte geloof dra die volle, ryke, vrymoedige liefdesgemeenskap met God in hom (Barton et al., 1997:170). 
4.2 Spoud áz w

(Heb. $4: 11 ; 6: 11$ )

Die begrip s poud áz w dui op die erns wat by 'n persoon bestaan om 'n bepaalde saak te onderneem (Louw en Nida, 1989a:298). Die erns wat die begrip beklemtoon, staan in 'n noue verband met toewyding. Louw en Nida, (1989a:288) plaas die begrip onder een van die subdomeine van gesindheid. Die begrip kan ook dui op die ywer of entoesiasme in die uitvoering van 'n taak (Flanigan, 1997:78). Volgens Bruce (1990:111); Bromiley (1985b:1070) en Douglas (1986b:454) dui die begrip selfs op die ernstige belangstelling oftewel toewyding wat getoon moet word in die uitvoering van ' $n$ saak. Die begrip kan ook beteken om haastig te wees om iets te doen of af te handel (Brown, 1986b:1168).

In die Hebreërspreek word die begrip soos volg gebruik:

- In Hebreërs 4:11 vermaan die prediker die hoorders om hulle te beywer om in die rus in te gaan. Volgens Brown (1986b:1169) dui die begrip in die vers die gelowige se verantwoordelikheid ten opsigte van geloofsgroei aan. Die hoorder se lewe moet gekenmerk word deur ywer in die geloof, aangesien die gevaar bestaan om jou lewensdoel te mis (Bruce, 1990:111). In dié vers word een van twaalf hortatiewe konjunktiewe in die Hebreërspreek aangetref (Kistemaker, 1984:115). Die begrip dui volgens Ellingworth (1993:258) hier op die erns, ywer en poging wat aangewend word, eerder as op die spoed waarmee 'n saak afgehandel word. Die begrip word dikwels saam met werkwoorde van beweging gebruik. In die vers staan die begrip in 'n noue verband met die woord e is ćr c o ma i . Flanigan (1997:78) en Ellingworth (1993:258) dui verder aan dat die begrip in Hebreërs dui op die vashou aan dit wat oor die jare aan gelowiges verkondig is. Volgens Evans (1984:104) het die begrip in die vers selfs die betekenis van inspanning. Die opdrag tot erns om in te gaan het die betekenis van beywer met inspanning.

- In Hebreërs 6:11 spreek die Hebreërsprediker die ernstige begeerte uit dat elkeen van die hoorders dieselfde ywer moet toon. Volgens Wilson (1996:81) spreek die Hebreërsprediker die wens uit binne die konteks waarin hy die hoorders opskerp tot geestelike groei. Die hoorders se traagheid om te hoor, gee aanleiding tot die vermaning tot groter ywer. Alhoewel daar wel onder die hoorders ywer vir die diens van die Here is, is daar tog duidelike tekens van verslapping (Evans, 1984:168). Owen (1999:102) maak op grond hiervan die gevolgtrekking dat pastorale aanmoediging tot groter ywer in God se diens noodsaaklik is - selfs onder omstandighede waar duidelike 
tekens van ywer in God se diens bestaan. Volgens Guthrie (1996:83) en Johnston (1994:50) het die hoorders nie genoegsaam vanuit die hoop gelewe nie. Indien die sekerheid van die hoop ontbreek, tree verslapping in die geloof in.

\subsection{Q a r roûnta"}

(Heb. 13:6)

In Hebreërs 13 is die Hebreërsprediker bekommerd oor 'n aantal beginsels wat by die hoorders agterweë gebly het. Die paranese het daarom in die hoofstuk 'n algemene aard (Wilson, 1996:188; Johnston, 1994:204). In dié hoofstuk word die hoorders deur middel van die prediking aangespoor om nie net met God in 'n gesonde verhouding te staan nie, maar ook met hulle naaste (Owen, 1999:268). Louw en Nida (1989a:306) plaas die begrip qarroûnta" binne die subdomein van moed of vrymoedigheid. Die begrip beteken vertroue en selfs beslistheid ten opsigte van die bereik van die doelwit te midde van gevaar (Louw \& Nida, 1989a:306).

Vines (1993:235) beskou Hebreërs 13 as 'n nadere omskrywing van die geloofsbelydenis wat die prediker en hoorders saam onderskryf. Die prediker het die hoorders by verskeie geleenthede opgeskerp tot 'n gesindheid van vrymoedigheid. Gesindheid impliseer immers 'n vrymoedigheid in God. In Hebreërs 13:5-6 word die begrip t r óp o " gebruik, in plaas van die erkende term $\alpha$ a s $\mathrm{t}$ r of $\eta \dot{\eta}$ as aanduiding van 'n persoon se gedrag (Flanigan, 1997:281). Die begrip t r óp o " dien as aanduiding van 'n persoon se manier van dink en lewe. 'n Gelowige se denke en optrede moet daarom vry wees van geldgierigheid. Gelowiges se lewens moet getuig van 'n tevredenheid in die wete dat God doen wat Hy beloof (Murray, 1996:528). Die vrymoedigheid en moed van 'n gelowige te midde van moeilike omstandighede lê opgesluit in God se troue sorg (Mahan, 1989:73).

\subsection{Samevattende basisteoretiese perspektiewe oor die gesindheid van hoorders}

Vanuit Hebreërs blyk dit dat predikers 'n opdrag het om sekere leemtes in die luisteraars se gesindheid ten opsigte van die Woordbediening te betrek. Die opdrag blyk vanuit die drie begrippe wat direk verband hou met die gesindheid van die hoorder in Hebreërs, naamlik par rhs ía, spoud ́́zw, qarroûnta". Die prediking is afgestem op sekere aspekte van die gelowiges se lewens en in die besonder sekere leemtes in hul 
gesindheid teenoor die prediking. Die drie begrippe het te make met die volgende:

- Die gesindheid van vrymoedigheid wat die hoorders onder alle omstandighede moet openbaar. Die vrymoedigheid wat gelowiges as gawe in Christus besit, moet as opdrag ook in die praktyk beoefen word. Daarom word gelowiges opgeroep om selfs onder moeilike omstandighede met vrymoedigheid tot God te nader. Die vrymoedigheid om tot God te nader, hou 'n genadeloon in. Die genadeloon behels onder andere die voorreg om in gemeenskap met God te staan en in sy seëninge te deel.

- Die gesindheid van erns wat by die hoorders ontwikkel om 'n bepaalde saak te hanteer of af te handel. Die gesindheid van erns dui op die hoorder se verantwoordelikheid ten opsigte van geloofsgroei. Gelowiges moet hulle met inspanning beywer om te groei in die geloof. Hoorders moet voortdurend groei in hulle ywer vir God se diens. Tussen ywer en hoop bestaan 'n noue band. Indien die sekerheid van hoop ontbreek, tree verslapping in die geloof in.

- Die gesindheid van moed en beslistheid ten opsigte van 'n gestelde doelwit. Die basis van die hoorders se moed lê opgesluit in die troos dat God sorg.

\section{Die gesindheidsdimensie ten opsigte van preke}

In dié paragraaf sal kortliks gefokus word op sekere uitdrukkings in die Hebreërspreek waaruit die gesindheid van die prediker en hoorders blyk. Die gesindheid ten opsigte van preke kom na vore in die volgende uitdrukkings:

\section{1 mh pote parar uw men - nie wegdrywe nie - (Heb. 2:1)}

Die Hebreërsprediker doen 'n beroep op sy hoorders om nog meer ag te gee op die prediking wat tot hulle kom (Hume, 1997:24). Louw en Nida (1989a:365) plaas die begrip par a r u $\omega$ men binne die subdomein van: 'n opinie huldig, om te glo of om te vertrou. Die begrip kan selfs beteken om jou vertroue in die waarheid prys te gee of om weg te dryf van die regte oortuiging af (Louw \& Nida, 1989a:375). In Hebreërs 2:1 spreek die Hebreërsprediker sy bekommernis daaroor uit dat die hoorders moontlik stadig maar seker dit waaraan hulle in die verlede onwrikbaar geglo het, kan opgee (Louw \& Nida, 1989a:375). Dit is daarom des te meer noodsaaklik dat die hoorders nog meer ag moet slaan op die prediking wat tot hulle kom. 


\section{2 nwqroivgegonate tai" akoai" - traag geword het om te hoor - (Heb. 5:11)}

Die Hebreërsprediker vermaan die hoorders oor hulle traagheid om te hoor. In die prediking was die Hebreërsprediker besig om die hoorders te onderrig oor Christus se priesterskap volgens die orde van Melgisedek. Hy onderbreek homself om hulle te vermaan (Murray, 1996:196). Die rede vir die onderbreking is die feit dat die hoorders suigelinge geword het in die hoor en hantering van die Woord (Brown, 1994:265; Venter, 1986:14). Volgens Venter (1986:14) bring die uitdrukking traag om te hoor' $n$ mens te staan by die kragveld van hoor en luister in die Nuwe Testament. Venter (1986:14) toon in sy navorsing aan dat hoor as aksie van ontvang van God se geopenbaarde wil van verlossing altyd bevestiging of aanvaarding van die hoorder eis. Hoor moet aanleiding gee tot gehoorsaamheid. Traagheid om te hoor dui op traagheid om God te gehoorsaam.

Die hoorders is so lank al gelowiges dat hulle teen dié tyd al ander moes leer. Die hoor van die Woord moes gehoorsaamheid en leer tot gevolg gehad het. Die term nwqro $i$ is 'n idiomatiese uitdrukking wat letterlik beteken om moeilik te hoor (Louw en Nida, 1989a:386). In Hebreërs 5:11 het die begrip die betekenis van luiheid, traagheid en stadig om te begryp. Evans (1984:127) toon aan dat die woord traagheid selfs kan beteken om momentum te verloor of om apaties teenoor 'n saak te staan. Die gesindheid van traagheid by die hoorders gee daartoe aanleiding dat die Hebreërsprediker hulle vermaan.

\section{3 dia Vpistew" kai makroqumi" - deurdie geloofen lankmoedigheid - (Heb. 6:12)}

In Hebreërs 6:10-12 bring die Hebreërsprediker die drie interafhanklike deugde van geloof, hoop en liefde na vore (Mahan, 1989:29). Die vermaning het 'n positiewe aard: indien die hoorders nie traag mag word nie, moet hulle navolgers ( $\mathrm{mi} h \mathrm{t} \mathrm{a} \grave{\mathrm{i}}$ ) word. Die begrip navolgers druk in hierdie verband die gesindheid van 'n volgeling uit (Ellingworth, 1993: 333). Die hoorders moet navolgers word van die volhardende geloof van hulle voorouers (Wilson, 1996:81). Die uitdrukking dia V pistew" kai ma k r o qu mi a druk die volhardende aspek van geloof uit. In dié vers spoor die Hebreërsprediker die hoorders aan tot 'n lankmoedige geloof (Hume, 1997:52).

Die begrip ma k r o qu mi घ beteken om lank uit te hou voordat byvoorbeeld aan woede toegegee word (Douglas, 1986:883). Vines (1993:98) sluit hierby aan met sy stelling dat die begrip lankmoedigheid dui op die beoefening van selfbeheersing ten opsigte van woede asook om geduld 
te hê met iemand se foute. Dié begrip vorm een van die subdomeine van gesindhede (Louw \& Nida, 1989a:289) en dui op 'n staat van emosionele kalmte selfs te midde van provokasie en irritasie (Louw \& Nida, 1989a: 307).

\section{4 oj egontai - verlang na - (Heb. 11:16)}

Louw en Nida (1989a:288) plaas die begrip o r ego ma i onder een van die subdomeine van gesindheid. Dié begrip beteken om ernstig daarna te streef om jou doel te bereik (Louw \& Nida, 1989a:291). Die begrip kan ook aspireer of strewe na iets beteken. In Hebreërs 11:16 word die begrip gebruik om die gelowige se ernstige strewe na die hemelse vaderland mee aan te dui.

\section{5 apraton wl of wh ekarterhsen - volgehou sooseen wat die Onsienlike sien - (Heb. 11:27)}

Die Hebreërsprediker vestig met dié frase die hoorders se aandag op die geloof waarsonder niemand onder moeilike omstandighede staande kan bly nie. Die gelowige het ook onder moeilike omstandighede die troos dat God die onsienlike toekoms in sy hande het (Phillips, 1992:164). Die begrip ekarterhs en beteken om sterk te wees, uit te hou, te volhard of te verduur (Ellingworth, 1993:616). Die begrip ekarterhs en saam met die partikel w " dui daarop om aan te hou (te volhard) om iets te doen (Ellingworth, 1993:617; Louw \& Nida, 1989a:308). Louw en Nida (1989a: 305) plaas die begrip in die semantiese veld van gesindhede as 'n subdomein van bemoediging of vertroosting.

\section{6 kamh te - nie vermoeid word nie - (Heb. 12:3)}

In Hebreërs 12:1-3 word die hoorders vermaan om nog meer erns te maak met geloofsvolharding. Die Hebreërsprediker noem vir sy hoorders die beeld van 'n vader wat sy kinders tug (Russell, 1996:141). Die tugtiging moet met vreugde aanvaar word omdat dit die bewys van kindskap is. Nadat die Hebreërsprediker die beeld aan die hoorders voorgehou het, wek hy hulle op tot 'n aktiewe daad (Flanigan, 1997:257).

In Hebreërs 12:3 word die ag gee op Jesus Christus verbind aan i f a mh V kamhte tai" yucai" umwh ekluomenoi. Die begrip kamhte is 'n aoristus-konjunktief. Die praesens passiewe deelwoord ek I u 0 me no i word verbind aan die werkwoord $k$ ámh te. Die deelwoord dui die manier aan waarop die hoorders nie vermoei moet word nie (Kistemaker, 1984:372). Die datief van betrekking tai" y ucai" staan op sy beurt in 'n noue verband met bogenoemde deelwoord. Phillips (1992:177) toon aan dat 
die hoorders vasgekyk het teen hulle beproewinge. Hulle moet noukeurig let op dit wat Jesus Christus gedoen het. Dit sal daartoe aanleiding gee dat hulle nie vermoeid word nie. Vermoeidheid en verslapping is twee begrippe wat interafhanklik is (Stedman, 1992:138).

Louw en Nida (1989a:288) plaas die begrip ka mh te binne die semantiese veld van gesindhede. Louw en Nida (1989a:319) plaas die begrip onder die subdomein van moedeloosheid. In Hebreërs 12:3 het die begrip die idiomatiese betekenis van om sielsmoeg te word. Die begrip beklemtoon die gedagte dat iemand stadig maar seker motivering verloor om sy doelwit te bereik (Louw \& Nida, 1989a:320).

\section{7 mh Vojigwrei paidei" - ag die tugtiging nie gening nie - (Heb. 12:5)}

In Hebreërs 12:5 vermaan die Hebreërsprediker sy hoorders op 'n sagte wyse. Hy vermaan hulle met 'n woord uit die Skrif (Russell, 1996:143). 'n Gelowige se lewe moet immers kongruent aan God se Woord wees. In Hebreërs 12:5 word 'n aanhaling uit Spreuke 3:11-12 gevind. Flanigan (1997:257) toon aan dat die Hebreërsprediker bekommerd is oor die hoorders se reaksie op God se tugtiginge. Die term mh V oligwrei beteken om iets ligtelik op te neem, om sonder respek op te tree of om iets as onbelangrik te beskou (Vines, 1993:208).

Louw en Nida (1989a:742) plaas die begrip of i g w v ei binne die semantiese veld van morele en etiese vereistes wat 'n noue band toon met gedrag. Ook plaas hulle (Louw \& Nida, 1989a:763) die begrip onder die subdomein om iets te verag of te minag. In Hebreërs 12:5 het die begrip die betekenis van om nie die tugtiging as van minder waarde te beskou nie (Louw \& Nida, 1989a:763). Die hoorders moet dus nooit God se tugtiginge ligtelik opneem nie.

\subsection{DiovtaV pareimena" ceira" kaivta Vparal el umena gonata a jor qw s a t e - rig die slap hande en knieë weer op - (Heb. 12:12.)}

Hebreërs $12: 12$ is gerig op 'n situasie van algehele mismoedigheid (Owen, 1999:252). Waarskynlik het die mismoedigheid onder die hoorders ingetree as gevolg van die tugtiging van die Here (Brown, 1994:633). Die vermaning wat tot die hoorders gerig word, word gerig in terminologie wat aan 'n atletiekwedloop herinner (Bruce, 1990:347). Die wedloop van die geloof verg die uiterste inspanning van gelowiges (Russell, 1996:141). In die wedloop van die geloof moet gelowiges die oog gerig hou op die einddoel, naamlik om die oorwinnaarskroon te verkry. 
Kistemaker (1984:381) gebruik 'n voorbeeld uit die sportwêreld wanneer hy daarop wys dat die Hebreërsprediker in die verse eintlik optree soos 'n afrigter wat met sy vermaning bemoedig. Ten spyte van die moegheid wat onder die hoorders ingetree het, moet hulle weer die slap hande en vermoeide knieë oprig. Die perfektum van die passiewe deelwoord t a V pareimena" ceila" staan in die vroulike meervoudsvorm. Die deelwoord beskryf die hande van gelowiges. Die perfektum van die passiewe deelwoord ta Vparal el umena is saamgestel uit para (aan die kant van) en I u $\hat{\omega}$ (ek maak los). Met dié uitdrukking word die aksie van die knieë ( $g \circ \| u)$ beskryf. Die werkwoord a jor q w s a te is 'n aoristus imperatief. Die werkwoord het die betekenis van oprig, herstel of versterk (Flanigan, 1997:261).

Louw en Nida (1989a:306) vestig die aandag daarop dat Hebreërs 12:12 'n idiomatiese uitdrukking is. Die idioom het die betekenis van om bemoediging op grond van 'n gewigtige besluit te kry of om jouself deur vasberadenheid te bemoedig (Louw \& Nida, 1989a:306).

\section{9 el w men ca rin - la at ons dankbaar wees - (Heb. 12:28)}

Die Hebreërsprediker het sy hoorders in Hebreërs 12:18-29 toegerus ten opsigte van die onwankelbare sake (Bruce, 1990:364-365). Aangesien hulle reeds die onwankelbare koninkryk ontvang het, moet hulle dankbaar teenoor God wees, want die onwankelbare koninkryk hou vir altyd stand (Kistemaker, 1984:401).

\subsection{Samevattende basisteoretiese perspektiewe}

In die Hebreërspreek word uitdrukkings aangetref waaruit die gesindheid van die hoorders ten opsigte van preke blyk. Hoorders word naamlik deur die prediking voor die opdrag geplaas word om hulle gesindhede in ooreenstemming met die Woord te bring. Die volgende begrippe dui op die gesindheid waarmee hoorders na preke behoort te luister deur:

- nog meer ag te gee op die prediking;

- hoorders te wys op hulle verkeerde gesindheid ten opsigte van hulle omgang met God se Woord;

- gelowiges op te roep om hulle toe te lê op die volle en dieper inhoud van die Woord van God - traagheid om die Woord van God te hoor, impliseer ongehoorsaamheid;

- die gesindheid van volharding te openbaar - indien hoorders in die geloof volhard, sal hulle nie traag word nie;

- in hulle geloofsverwagtng ernstig te strewe na die hemelse dinge; 
- onder alle omstandighede te bly volhard in die geloof - soos een wat die Onsienlike sien;

- te waak teen 'n verkeerde gesindheid van moedeloosheid - moedeloosheid gee daartoe aanleiding dat hoorders hul motivering in die geloofstryd en sodoende ook hulle fokus verloor;

- nie die tugtiginge van God ligtelik op te neem nie - die tugtiginge dien juis as bewys van kindskap;

- 'n gesindheid van inspanning in die geloofswedloop toon en nog meer gedetermineerd te wees ten opsigte van die wedloop;

- 'n gesindheid van dankbaarheid te openbaar.

6. Ba sisteoretiese perspektiewe op prediking en die gesindheid van hoorders - samevattende stellings

- In gemeentelike bediening moet prediking beskou word as een van die vernaamste wyses van toerusting. In die toerusting moet rekening gehou word met die veelkantigheid van die prediking soos dit na vore kom in die volgende aspekte:

- Prediking as paraklese hou rekening met die tweekantigheid van prediking as vermaning en vertroosting.

- Prediking as gesprek dui daarop dat prediking eg en eenvoudig moet wees en God se Woord as inhoud moet hê.

- Prediking as evangelieverkondiging bring aan hoorders die blye boodskap met die appèl om die toesegging deur die geloof toe te eien.

- Prediking as getuienis bring aan hoorders die getuienis oor die waarheid van die Woord.

- Prediking dien as motivering vir hoorders om gesindhede wat nie in ooreenstemming met die Woord is nie te verander. Die Woord is dus die instellings- en vertrekpunt vir die verandering van gesindhede.

- Die volgende gesindhede ten opsigte van hulle geloofslewe moet by hoorders aanwesig wees:

- Die vrymoedigheid wat gelowiges in Christus besit, moet ook in die praktyk uitgeleef word.

- Gelowiges moet erns ten opsigte van geloofsgroei toon.

- Hoorders moet moed en beslistheid openbaar in die uitlewing van hulle roeping. 
- Die hoorders van die prediking openbaar almal gesindhede oor God, die Woord, die prediking, die prediker en die gemeente. Dié gesindhede word primêr gevorm deur die ervaring wat hoorders oor jare heen opgedoen het. Die gesindhede kan wissel van positief tot negatief. Prediking as oorredingskommunikasie is 'n instrument saam met die ander gestaltes van Woordverkondiging in die gemeentelike bediening waardeur gesindhede gevorm, verander of gehandhaaf kan word.

\section{Bibliografie}

ATTRIDGE, H.W. 1989. The epistle to the Hebrews. Philadelphia : Fortress.

BARTON, B.B., VEERMAN, D. \& TAYLOR, L.K. 1997. Hebrews. Life Application Bible Commentary. Wheaton: Tyndale House.

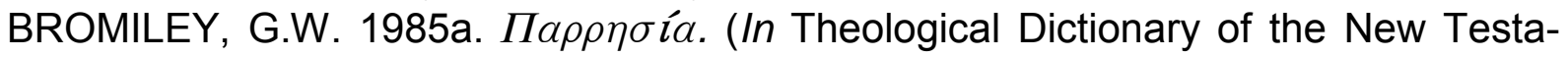
ment. Grand Rapids, Mich. : Eerdmans. p. 794-795.)

BROMILEY, G.W. 1985b. $\Sigma \pi o v \delta \alpha ́ \zeta \zeta$. (In Theological Dictionary of the New Testament. Grand Rapids, Mich. : Eerdmans. p. 1069-1070.)

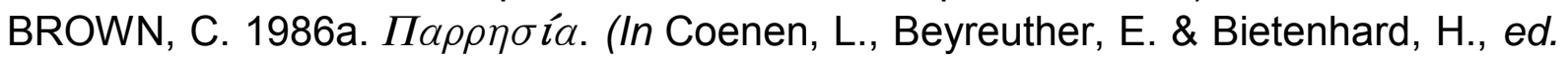
The New International Dictionary of the New Testament Theology II. Grand Rapids, Mich. : Zondervan. p. 734-737.)

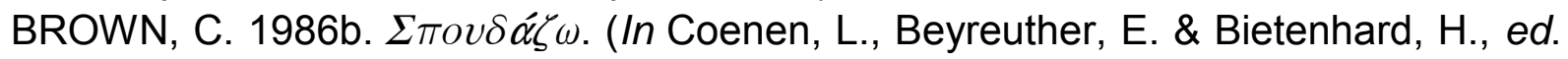
The New International Dictionary of the New Testament Theology III. Grand Rapids, Mich. : Zondervan. p. 1168-1169.)

BROWN, J. 1994. Hebrews. Geneva Series of Commentaries. Edinburgh : The Bath Press.

BRUCE, F.F. 1990. The Epistle to the Hebrews. The New International Commentary of the New Testament. Grand Rapids : Eerdmans.

BURGER, C.W. 1995. Gemeentes in transito. Vernuwingsgeleenthede in 'n oorgangstyd. Kaapstad : Lux Verbi.

CONN, H.M. 1984. Eternal Word and changing worlds. Grand Rapids : Zondervan.

COETZEE, J.C. 1986. Gedagtestruktuur van Hebreërs. Potchefstroom : Fakulteit Teologie.

CRADDOCK, F.B. 1991. Preaching. Nashville : Abingdon.

DE WET, F.W. 1995. Die kritiese element in die luisterproses. ' $n$ Homiletiese studie. Potchefstroom : PU vir CHO. (Verhandeling - Th.M.)

DINGEMANS, G.D.J. 1991. Als hoorder onder de hoorders. Kampen : Kok.

DOUGLAS, J.D. 1986. $\Sigma \pi 0 v \delta \alpha ́ \zeta \zeta \omega$. (In New Bible Dictionary. Wheaton: Callenbach. p. 454.)

ELLINGWORTH, P. 1993. Commentary on Hebrews. New International Greek Testament Commentary. Grand Rapids : Eerdmans.

EVANS, L.H. 1984. Hebrews. The communicators commentary. Washington : Macmillan.

FLANIGAN, J.M. 1997. Hebrews - What the Bible teaches. Ritchie New Testament Commentaries. Kilmarnock : John Ritchie.

GUTHRIE, D. 1996. Hebrews Tyndale New Testament Commentaries. Grand Rapids : Eerdmans.

HERHOLDT, S.J. 1995. Die prediking van Handelinge 5:27-32. (In Burger, C.W., Muller, B.A. \& Smit, D.J., red. Verdere riglyne vir Paas-, Hemelvaart en Pinksterprediking. Kaapstad : Lux Verbi. p. 117-130.) 
HUME, C.R. 1997. Reading through Hebrews. Lymington : The Spartan.

HURST, L.D. 1990. The epistle to the Hebrews: Its background of thought. Cambridge : Cambridge University Press.

JOHNSTON, W.B. 1994. The epistle to the Hebrews. Calvin's Commentaries. Grand Rapids : Eerdmans.

KISTEMAKER, S.J. 1984. Hebrews. New Testament Commentary. Grand Rapids : Baker Book House.

LANE, W.L. 1991. Hebrews 1-8. Dallas: World Books.

LONG, T.G. 1989. The preaching of the literary forms of the Bible. Philadelphia : Fortress Press.

LOUW, D.J. 1993. Pastoraat as ontmoeting. Ontwerp vir 'n basisteorie, antropologie, metode en terapie. Pretoria : RGN.

LOUW, J.P. \& NIDA, E.A. 1989a. Greek English lexicon of the New Testament. Vol. I. New York : United Bible Studies.

LOUW, J.P. \& NIDA, E.A. 1989b. Greek English lexicon of the New Testament. Vol. II. New York : United Bible Studies.

MACK, W.A. \& SWAVELY, D. 1996. Life in the Father's house. A member's guide to the local church. New Yersey : P. \& R. Publishing.

MAHAN, H.T. 1989. Hebrews. Darlington : Evangelical Press.

MURRAY, A. 1996. The holiest of all. New. Kensington : Whitaker.

OPPERMAN, W.C. 1995. Die motief van vreemdelingskap en vaderland in Hebreërs - 'n eksegetiese studie met toespitsing op Hebreërs 11:8-22. Potchefstroom : PU vir CHO. (Proefskrif - Th.D.)

OWEN, J. 1999. Epistle to the Hebrews. Grand Rapids : Kregel.

PETERS, M.A. 1999. Hebrews 10:19-25: Between text and sermon. Interpretation, 53(1):62-64.

PFITZNER, V.C. 1993. The rhetoric of Hebrews: Paradigm for preaching. Lutheran Theological Journal, 27 (5):3-12.

PHILLIPS, J. 1992. Exploring Hebrews. New Jersey : Loiszeaux Brothers.

PIETERSE, H.J.C. 1985. Verwoording en prediking. Pretoria : N.G. Kerkboekhandel.

PIETERSE, H.J.C. 1991. Gemeente en prediking. Halfway House : N.G. Kerkboekhandel.

RUSSELL, B.A. 1996. Fixing your eyes on Jesus. South African Baptist Journal of Theology, 5:140-148.

SCHOONEES, P.C., hoofred. 1972. Woordeboek van die Afrikaanse Taal. Pretoria : Staatsdrukker.

SMIT, A. 1995. Nuut gedink oor leierskap in gemeentes. (In Burger, C., Hendriks, J., Van der Merwe, M. \& Smit, A., reds. Gemeente en bediening. Nuut gedink oor leierskap in gemeentes. Die begeleiding van 'n Christelike gemeenskap. Kaapstad : Lux Verbi. p. 16-36.)

STEDMAN, R.C. 1992. Hebrews (IVP New Testament Commentary Series.) Illinois : Intervarsity Press.

SPRING, G. 1986. The power of the pulpit. Edinburgh : The Spartan Press.

VAN DER VYVER, L. du P. 1990. Die rol van die hoorder in die prediking. Potchefstroom : PU vir CHO. (Verhandeling - Th.M.)

VENTER, C.J.H. 1986. Gemeente-opbou in die lig van Hebreërs. Potchefstroom : Departement Sentrale Publikasies. (Wetenskaplike bydraes van die PU vir $\mathrm{CHO}$. Reeks H: Inougurele Rede nr. 103.)

VENTER, C.J.H. 1988. Die Gees, die Woord en die bedienaar van die Woord. (In Coetzee, J.C., red. Koninkryk, Gees en Woord. Pretoria : N.G. Kerkboekhandel. p. 141-162.) 
VENTER, C.J.H. 1993. Basisteoretiese perspektiewe op kommunikasie in die bediening. In die Skriflig, 27(2):187-201, Junie.

VENTER, C.J.H. 2001. Verklarende prediking - 'n herevaluering. Potchefstroom : Fakulteit Teologie.

VINES, J. 1993. The believers guide to Hebrews. New Jersey : Loizeaux.

VORSTER, J.M. 1995. Vernuwing in die prediking in die lig van hedendaagse lewensbeskoulike tendense. In die Skriflig, 29(3):443-466, Maart.

VORSTER, J.M. 1998. Die toerustingstaak van die Gereformeerde predikant: 'n praktiese bedieningsmodel. In die Skriflig, 32(1):19-36.

VOS, C.J.A. 1994. Die blye tyding. Homiletiek uit 'n hermeneuties kommunikatiewe WAT perspektief. Pretoria : RGN Uitgewery.

kyk Schoonees, P.C. et al.

WILLIAMS, D.T. 1996. After the order of Melchizedek: Pre-existence and salvation in Hebrews. The South African Baptist Journal of Theology, 5:1-7.

WILSON, G.B. 1996. Hebrews. Edinburgh : BPC Paperbacks.

WILSON, R. 1987. Hebrews. Grand Rapids : Eerdmans.

ZERFASS, R. 1982. Mit der Gemeinde predigen. Düsseldorf : Gutersloh.

\section{Kernbegrippe:}

gesindheid

Hebreërs

hoorders

prediking

\section{Key concepts:}

attitude

hearers

Hebrews

preaching 